\title{
TEKANAN EKONOMI DAN STRATEGI KOPING KELUARGA PETANI DI DAERAH RAWAN BANJIR
}

\author{
Tri Wulandari Henny Astuti ${ }^{*{ }^{*}}$, Hartoyo ${ }^{2}$, Istiqlaliyah Muflikhati ${ }^{2}$ \\ 1Direktorat Bina Lini Lapangan, Badan Kependudukan dan Keluarga Berencana Nasional, \\ Jakarta 13650, Indonesia \\ 2Departemen IImu Keluarga dan Konsumen, Fakultas Ekologi Manusia, Institut Pertanian Bogor, \\ Bogor 16680, Indonesia
}

*)E-mail: wulan.rara18@gmail.com

\begin{abstract}
Abstrak
Penelitian ini bertujuan untuk menganalisis pengaruh karakteristik keluarga dan tekanan ekonomi terhadap strategi koping keluarga petani di daerah rawan banjir, Kabupaten Kebumen. Keluarga petani yang terlibat dalam penelitian berjumlah 100 keluarga terdiri atas 50 keluarga dari Desa Kemujan dan 50 keluarga dari Desa Tegalsari. Data dianalisis menggunakan analisis deskriptif, uji beda $t$, dan uji regresi linier berganda. Keluarga petani mempersepsikan tekanan ekonomi keluarga mereka pada kategori sedang. Strategi koping ekonomi yang dilakukan keluarga petani juga tergolong sedang, akan tetapi untuk kategori intensitas melakukan strategi koping keluarga petani pada tingkat rendah. Tekanan ekonomi keluarga meningkat dengan bertambahnya jumlah tanggungan keluarga dan jenis bantuan pemerintah yang pernah diterima. Sebaliknya, tekanan ekonomi keluarga menurun seiring bertambahnya luas rumah-pekarangan dan juga perubahan status kepemilikan rumah dari tidak memiliki rumah ke memiliki rumah. Tekanan ekonomi keluarga berpengaruh pada strategi koping baik dari sisi jumlah maupun intensitasnya. Faktor lain yang menentukan strategi koping keluarga adalah adalah usia suami, pekerjaan sampingan suami, dan pekerjaan istri. Banyaknya dan intensitas strategi koping yang dilakukan keluarga bertambah dengan bertambahnya usia suami dan kepemilikan pekerjaan pada istri. Banyaknya strategi koping yang dilakukan juga bertambah dengan suami memiliki pekerjaan sampingan. Penelitian ini menunjukkan eratnya hubungan antara tekanan ekonomi dengan strategi koping keluarga petani di daerah rawan banjir.
\end{abstract}

Kata kunci: daerah rawan banjir, keluarga petani, strategi koping, tekanan ekonomi

\section{Economic Pressure and Coping Strategies of Farmer Family in Flash Flood Areas}

\begin{abstract}
This study aimed to analyze the influence of family characteristics and economic pressure on coping strategies of farmer families in flash flood areas, Kebumen District. Farmer families that involved in the study were 100 families consisting of 50 families from the village of Kemujan and 50 families from the village of Tegalsari. Data were analyzed using descriptive analysis, different $t$ test, and multiple linear regression. Farmer family perceived the economic pressure of their family in the medium category. Economic coping strategies which were done by farmer family are also classified as moderate, but the intensity of coping strategies done by farmer family was categorized into low level. Economic pressure of family increases with the number of family burden and the type of government assistance that has been received. In contrast, the economic pressure decreases as the increase of home-grounds and also the change of ownership status of the house. Economic pressure of family affects the coping strategies both in number and intensity. Another factor that determines coping strategies of family is the age of the husband, the husbands' side job, and the wife's work. The number and intensity of coping strategies that family has will increase in line with the age of husband and a condition when wife has a job. The number of coping strategies done by family also increases if husband has side job. This research shows the close relationship between economic pressure and coping strategies of farmer family in flash flood areas.
\end{abstract}

Keywords: coping strategies, economic pressure, farmer family, flash flood areas

\section{PENDAHULUAN}

Banjir merupakan bencana alam paling sering terjadi baik dilihat dari intensitas pada suatu tempat maupun jumlah lokasi kejadian. Provinsi Jawa Tengah merupakan provinsi yang memiliki jumlah kejadian banjir tertinggi di
Indonesia yaitu sebanyak 3.180 kejadian (BNPB, 2014). Bencana alam khususnya banjir dapat menyebabkan tekanan ekonomi keluarga seperti hilangnya harta benda, kerusakan, dan terganggunya aktivitas mata pencaharian. Bagi keluarga petani, terbatasnya lahan dan rusaknya lahan akibat banjir maupun bencana 
alam lainnya mengakibatkan berkurangnya lapangan kerja dan sumber ekonomi untuk kelangsungan hidup. Selain itu, bencana banjir juga dapat mengakibatkan kerugian pada korban manusia dan harta benda, baik milik perorangan maupun milik umum yang dapat mengganggu dan melumpuhkan kegiatan sosial dan ekonomi masyarakat (Mislan, 2011).

Bencana banjir mengakibatkan tekanan ekonomi pada keluarga. Elder et al. (1992) menyebutkan bahwa terdapat tiga pengukuran mengenai tekanan ekonomi, yaitu tingkat pendapatan, perubahan pendapatan yang merugikan, dan status pekerjaan yang tidak stabil. Ketiga pengukuran tersebut memiliki pengaruh langsung terhadap kesehatan baik secara emosional atau hubungan keluarga. Sementara itu, kebutuhan hidup yang cukup bervariasi dan daya beli yang semakin melonjak menimbulkan tekanan baik fisik maupun mental terhadap anggota keluarga (Tati, 2004).

Voydanof, Majka, dan Donelly (1988) menyebutkan bahwa tekanan ekonomi meliputi empat tipe, yaitu ketidakstabilan kerja, ketidakpastian kerja, kesulitan ekonomi, dan ketegangan ekonomi. Hasil penelitian yang dilakukan oleh Sunarti (2012) menyebutkan bahwa keluarga dengan pekerjaan yang tidak stabil memiliki tekanan keluarga (meliputi ekonomi, sosial, dan psikologis) yang lebih besar dibandingkan dengan hal yang sama dari keluarga dengan pekerjaan stabil.

Faktor ekonomi merupakan salah satu indikator dari kesejahteraan hidup khususnya dalam kehidupan keluarga. Faktor ekonomi dapat menimbulkan tekanan dalam kehidupan keluarga sebagai dampak dari krisis yang berkepanjangan. Kajian beberapa literatur menunjukkan bahwa penyebab tekanan ekonomi yang ada di masyarakat pada umumnya yang dapat mengganggu tercapainya tingkat kesejahteraan keluarga adalah musim paceklik (Kusumo, 2009), stres karena kesulitan ekonomi (Gudmunson, 2010), berpenghasilan rendah dan kemiskinan (Gutman \& Eccles, 1999; Mcloyd, 1990), kehilangan pendapatan dan kehilangan pekerjaan, resesi ekonomi, depresi, hutang (Barrera et al., 2002; Elder, 1995; Whitbeck et al., 1991), perbandingan pendapatan dengan pengeluaran, kehilangan pendapatan, pekerjaan yang tidak stabil (Dennis et al., 2003; Elder et al., 1992), tekanan keuangan, pemutusan hubungan kerja (PHK), dan ketidakamanan kerja (Voydanoff, Majka, \& Donelly, 1988; Feil, 2012).
Jika tekanan ekonomi yang ditimbulkan dari bencana banjir dapat dikelola dengan strategi koping yang baik dan sesuai, keluarga petani dapat mengurangi dampak dari masalah ekonomi yang dihadapi, sehingga pada akhirnya keluarga petani mampu menciptakan kondisi kehidupan yang lebih baik. Dengan demikian, keluarga petani perlu memiliki strategi koping ekonomi, yaitu upaya untuk mengatasi masalah melalui usaha-usaha dalam bidang ekonomi untuk memenuhi kebutuhan keluarga, yang meliputi strategi penghematan dan strategi penambahan pendapatan agar pemenuhan kebutuhan pokok keluarga tetap bisa terjaga. Feil (2012) menyebutkan bahwa untuk mengatasi stres karena kesulitan ekonomi adalah dengan melakukan koping, seperti melakukan strategi-strategi yang dapat mengatasi stres. Keluarga pada umumnya melakukan penyesuaian ekonomi atau pengurangan pengeluaran untuk menghadapi tekanan ekonomi yang menyebabkan kesulitan ekonomi (Elder et al., 1992).

Berdasarkan pemaparan tersebut, analisis mengenai tekanan ekonomi dan strategi koping keluarga petani di daerah rawan banjir sangat diperlukan dalam mengatasi tekanan ekonomi yang diakibatkan oleh kesulitan ekonomi yang dialami keluarga petani di daerah rawan banjir. Selain itu, penggunaan strategi koping ekonomi yang sesuai juga berguna untuk meminimalkan tekanan ekonomi yang dirasakan keluarga petani di daerah rawan banjir yang mengalami kerugian baik fisik maupun nonfisik. Penelitian ini bertujuan untuk mengidentifikasi karakteristik keluarga, tekanan ekonomi keluarga, dan strategi koping keluarga di daerah rawan banjir. Penelitian juga dilakukan untuk menganalisis perbedaan tekanan ekonomi dan strategi koping keluarga petani berdasarkan lokasi tempat tinggal. Tujuan penelitian berikutnya adalah untuk menganalisis pengaruh karakteristik keluarga dan tekanan ekonomi terhadap strategi koping keluarga petani di daerah rawan banjir.

\section{METODE}

Penelitian ini menggunakan desain cross sectional yang dilaksanakan di Desa Kemujan dan Desa Tegalsari, Kecamatan Adimulyo, Kabupaten Kebumen, Provinsi Jawa Tengah. Pemilihan lokasi berdasarkan pertimbangan bahwa kecamatan ini adalah kecamatan yang paling parah dilanda banjir (BNPB, 2014). Kecamatan Adimulyo terdiri atas 23 desa dan hampir seluruhnya adalah daerah rawan banjir. Selanjutnya, pemilihan dua desa dilakukan secara purposif, yaitu satu desa yang terletak di 
dekat ibu kota kecamatan dan satu desa yang terletak jauh dari ibu kota kecamatan. Pemilihan letak desa dengan asumsi bahwa keluarga petani yang bertempat tinggal di desa yang letaknya dekat dengan ibu kota kecamatan lebih sejahtera dibandingkan dengan keluarga petani yang tinggal di desa yang jauh dari ibu kota kecamatan. Pengambilan data dilakukan pada bulan Juni sampai dengan bulan Agustus 2014.

Populasi dalam penelitian ini adalah kepala keluarga yang bekerja sebagai buruh tani di daerah rawan banjir Kabupaten Kebumen, Provinsi Jawa Tengah. Contoh dalam penelitian ini adalah keluarga buruh tani yang mengalami bencana banjir pada bulan Desember 2013. Teknik pengambilan contoh dilakukan dengan multiple stage dengan cara mengumpulkan populasi keluarga buruh tani di dua lokasi Desa Kemujan ( $\mathrm{N}=93$ keluarga) dan Desa Tegalsari ( $N=110$ keluarga). Selanjutnya, masing-masing desa dipilih sebanyak 50 keluarga secara acak sederhana (simple random sampling). Dengan demikian, contoh penelitian berjumlah 100 keluarga.

Pengumpulan data dalam penelitian ini dilakukan dengan wawancara menggunakan kuesioner. Karakteristik keluarga terdiri atas usia suami, jumlah tanggungan keluarga, lama pendidikan suami, luas rumah beserta pekarangan, pendapatan per kapita, pekerjaan sampingan suami, pekerjaan istri, status kepemilikan rumah, bantuan pemerintah yang pernah diterima keluarga petani, dan lokasi tempat tinggal.

Persepsi tekanan ekonomi diukur berdasarkan anggapan rasa khawatir dan sedih karena kerugian yang dialami ketika banjir, kesulitan ekonomi, peningkatan pemenuhan dan pengeluaran kebutuhan. Instrumen yang digunakan memiliki nilai Cronbach's alpha sebesar 0,897 yang terdiri atas 42 pertanyaan dengan empat pilihan jawaban, yaitu tidak pernah (skor 0), kadang-kadang (skor 1), sering (skor 2), dan selalu (skor 3). Skor yang diperoleh kemudian dihitung indeksnya dan dikategorikan berdasarkan tiga kategori yaitu rendah (indeks 0,0-33,3), sedang (indeks 33,466,6 ), dan tinggi (indeks 66,7-100,0).

Strategi koping ekonomi yang dijalankan oleh keluarga buruh tani di daerah rawan banjir ketika terjadi penurunan pendapatan terdiri atas tiga kegiatan, yaitu strategi menambah pendapatan, strategi mengurangi pengeluaran, dan strategi koping ekonomi lainnya (hutang, mengambil tabungan, menjual atau meng- gadaikan barang-barang). Data strategi koping ekonomi diberi skor 1 untuk jawaban "Ya" dan skor 0 untuk jawaban "Tidak". Strategi koping ekonomi menambah pendapatan, mengurangi pengeluaran, dan strategi koping lainnya secara keseluruhan dikelompokkan menjadi tiga, yaitu sedikit ( $\leq 12$ kegiatan), sedang (13-24 kegiatan), dan banyak (25-36 kegiatan). Selain itu, diukur juga intensitas atau seberapa sering strategi koping dilakukan yang diukur melalui pertanyaan dari instrumen yang digunakan untuk mengukur intensitas melakukan strategi koping. Instrumen ini memiliki nilai Cronbach's alpha sebesar 0,985 yang terdiri atas 42 pertanyaan. Setiap pertanyaan disediakan 4 jawaban, yaitu skor 0 untuk jawaban "Tidak pernah", skor 1 untuk jawaban "Kadangkadang", skor 2 untuk jawaban "Sering", dan skor 3 untuk jawaban "Selalu". Selanjutnya, skor dijumlahkan dan dihitung indeksnya serta dikategorikan menjadi tiga kategori tingkat intensitas melakukan strategi koping, yaitu rendah atau jarang (indeks 0,0-33,3), sedang atau sering (indeks $33,4-66,6$ ), dan tinggi atau sangat sering (indeks 66,7-100,0).

Analisis statistik yang digunakan dalam penelitian ini adalah analisis deskriptif, uji beda $t$, dan uji regresi linear berganda. Uji beda $t$ digunakan untuk membedakan variabel penelitian berdasarkan lokasi tempat tinggal keluarga petani yang dekat dan jauh dari kantor kecamatan. Uji regresi linier berganda digunakan untuk menguji pengaruh karakteristik keluarga terhadap tekanan ekonomi, serta pengaruh karakteristik keluarga dan tekanan ekonomi terhadap strategi koping keluarga.

\section{HASIL}

\section{Karakteristik Keluarga Petani}

Karakteristik keluarga terdiri atas usia suami, jumlah tanggungan keluarga, lama pendidikan suami, luas rumah beserta pekarangan, pendapatan per kapita, pekerjaan sampingan suami, pekerjaan istri, status kepemilikan rumah, bantuan pemerintah yang pernah diterima keluarga petani, dan lokasi tempat tinggal. Rata-rata usia suami adalah 44,9 tahun yang tergolong dalam dewasa madwa (40-60 tahun). Lama pendidikan suami berada pada rentang 1-12 tahun, dengan rata-rata sebesar 7,9 tahun. Rata-rata lama pendidikan suami dari keluarga petani ini dinilai rendah apabila dibandingkan dengan rata-rata lama pendidikan di Indonesia yaitu 8,3 tahun untuk laki-laki. Sebagian besar keluarga petani tergolong dalam keluarga kecil dengan jumlah tanggungan keluarga kurang dari 4 orang. 
Rata-rata pendapatan per kapita keluarga petani adalah Rp349.250,00 per bulan, angka ini lebih tinggi dari Garis Kemiskinan Provinsi Jawa Tengah untuk pedesaan pada September 2013 yaitu sebesar Rp256.368,00. Lebih dari 70 persen keluarga petani memiliki pekerjaan lain di samping pekerjaan utama suami sebagai buruh tani. Lebih dari setengah keluarga petani memiliki istri yang bekerja sebagai buruh tani, sisanya tidak memiliki pekerjaan dan bekerja pada bidang lain. Rata-rata luas rumahpekarangan keluarga petani adalah 29,4 ubin atau sekitar 414,1 $\mathrm{m}^{2}$. Lebih dari separuh keluarga petani $(55,0 \%)$ sudah memiliki rumah sendiri.

Banyaknya bantuan pemerintah yang pernah diterima keluarga petani bervariasi, sebagian besar keluarga menerima tujuh jenis bantuan. Jenis bantuan yang pernah diterima oleh keluarga petani meliputi program Keluarga Berencana (KB), Beras miskin (Raskin), Jaminan kesehatan masyarakat (Jamkesmas), Rumah Tidak Layak (RTL), Bantuan Tunai Langsung (BLT), Bantuan Operasional Sekolah (BOS), Jaminan persalinan (Jampersal), serta bantuan bencana banjir. Jenis bantuan yang paling banyak diterima oleh keluarga petani adalah bantuan beras untuk keluarga miskin (raskin), dan jaminan kesehatan (jamkesmas).

Tidak ada perbedaan signifikan pada karakteristik keluarga di Desa Tegalsari dan Desa Kemujan. Namun, hanya jumlah tanggungan keluarga saja yang memiliki perbedaan signifikan $(p<0,05)$ yang mana keluarga di Desa Kemujan (rata-rata 3,98 orang) memiliki lebih banyak jumlah tanggungan keluarga dibandingkan dengan keluarga di Desa Tegalsari (rata-rata 3,70 orang). Hal ini diindikasikan bahwa keluarga di Desa Kemujan lebih banyak memiliki jumlah anak usia sekolah dan balita.

\section{Tekanan Ekonomi}

Berdasarkan kategori persepsi tekanan ekonomi, persentase terbesar keluarga contoh di Desa Kemujan dan desa Tegalsari termasuk dalam tingkat sedang yaitu sebanyak 46,0 persen keluarga. Keluarga yang mengalami persepsi tekanan ekonomi pada kategori tinggi sebanyak 36,0 persen dan rendah $(18,0 \%)$. Apabila dilihat berdasarkan masing-masing pada kedua desa, keluarga di Desa Kemujan yang memiliki persepsi tekanan ekonomi kategori sedang $(42,0 \%)$ merupakan proporsi tertinggi. Begitu juga di Desa Tegalsari yang berkategori sedang $(50,0 \%)$ juga merupakan proporsi terbesar.
Hasil uji beda dalam penelitian menunjukkan terdapat perbedaan signifikan antara indeks persepsi tekanan ekonomi pada keluarga di Desa Kemujan dan Desa Tegalsari ( $p$ value $=0,024)$. Tingkat persepsi tekanan ekonomi keluarga di Desa Kemujan lebih rendah (dengan rata-rata indeks 53,46) dibandingkan dengan Desa Tegalsari (dengan rata-rata indeks 59,21). Hal ini diketahui ketika mengalami kerugian banjir, keluarga di Desa Kemujan lebih banyak mendapatkan bantuan dari pemerintah dibandingkan dengan keluarga di Desa Tegalsari, karena akses menuju Desa Kemujan lebih mudah sehingga menyebabkan tingkat persepsi tekanan ekonomi yang dirasakan keluarga Desa Kemujan lebih rendah.

\section{Strategi Koping Ekonomi}

Strategi koping yang dilakukan oleh keluarga terdiri atas tiga kategori yaitu rendah $(\leq 12$ kegiatan), sedang (13-24 kegiatan), dan tinggi (25-36 kegiatan). Rata-rata Pada Tabel 1 menunjukkan bahwa strategi koping yang dilakukan oleh keluarga petani yang tinggal di desa yang dekat dengan ibu kota kecamatan (Kemujan) termasuk dalam kategori sedang yaitu 13-24 kegiatan (74,0\%). Sementara itu, persentase tertinggi strategi koping yang dilakukan oleh keluarga petani yang tinggal di desa yang jauh dari ibu kota kecamatan (Tegalsari) termasuk dalam kategori tinggi yaitu 25-36 kegiatan $(50,0 \%)$. Secara umum, strategi koping termasuk dalam kategori sedang $(61,0 \%)$. Selanjutnya rata-rata strategi koping ekonomi Desa Kemujan adalah 24,66 dan Desa tegalsari adalah 21,92 rata-rata strategi koping ekonomi secara keseluruhan adalah 24,93.

Tabel 1 Sebaran keluarga berdasarkan kategori banyaknya strategi koping ekonomi secara keseluruhan dan lokasi tempat tinggal

\begin{tabular}{|c|c|c|c|}
\hline Kategori & $\begin{array}{c}\text { Kemujan } \\
(\%)\end{array}$ & $\begin{array}{l}\text { Tegalsari } \\
(\%)\end{array}$ & $\begin{array}{l}\text { Total } \\
(\%)\end{array}$ \\
\hline $\begin{array}{l}\text { Sedikit ( } \leq 12 \\
\text { kegiatan) }\end{array}$ & 0,0 & 2,0 & 1,0 \\
\hline $\begin{array}{l}\text { Sedang (13-24 } \\
\text { kegiatan) }\end{array}$ & 74,0 & 48,0 & 61,0 \\
\hline $\begin{array}{l}\text { Banyak (25-36 } \\
\text { kegiatan) }\end{array}$ & 26,0 & 50,0 & 38,0 \\
\hline Total & 100,0 & 100,0 & 100,0 \\
\hline $\begin{array}{l}\text { Minimum- } \\
\text { maksimum } \\
\text { (kegiatan) }\end{array}$ & $14 \pm 34$ & $12 \pm 36$ & $12 \pm 36$ \\
\hline $\begin{array}{l}\text { Rata-rata } \pm \\
\text { Standar deviasi } \\
\text { (kegiatan) }\end{array}$ & $\begin{array}{c}24,66 \pm \\
4,843\end{array}$ & $\begin{array}{c}21,92 \pm \\
3,773\end{array}$ & $\begin{array}{c}24,93 \pm \\
4,553\end{array}$ \\
\hline$p$-value & & 0,072 & \\
\hline
\end{tabular}


Tabel 2 Sebaran keluarga berdasarkan kategori intensitas melakukan strategi koping ekonomi secara keseluruhan dan lokasi tempat tinggal

\begin{tabular}{lccc}
\hline \multicolumn{1}{c}{ Kategori } & $\begin{array}{c}\text { Kemujan } \\
(\%)\end{array}$ & $\begin{array}{c}\text { Tegalsari } \\
(\%)\end{array}$ & $\begin{array}{c}\text { Total } \\
(\%)\end{array}$ \\
\hline $\begin{array}{l}\text { Rendah/jarang } \\
\text { (indeks<33,3) }\end{array}$ & 8,0 & 18,0 & 13,0 \\
$\begin{array}{l}\text { Sedang/sering } \\
\text { (indeks 33,4- }\end{array}$ & 92,0 & 82,0 & 87,0 \\
$\begin{array}{l}\text { 66,6) } \\
\text { Tinggi/sangat }\end{array}$ & 0,0 & 0,0 & 0,0 \\
$\begin{array}{l}\text { sering (indeks } \\
66,-100,0)\end{array}$ & & & \\
\hline $\begin{array}{l}\text { Total } \\
\text { Minimum- } \\
\text { maksimum } \\
\text { (indeks) }\end{array}$ & 100,0 & 100,0 & 100,0 \\
$\begin{array}{l}\text { Rata-rata } \pm \\
\text { Standar deviasi } \\
\text { (indeks) }\end{array}$ & $43,61 \pm$ & $19 \pm 58$ & $19 \pm 60$ \\
p-value & 9,051 & 7,941 & \pm \\
\hline & & & 8,740 \\
\hline
\end{tabular}

Hasil uji beda menunjukkan bahwa tidak terdapat perbedaan yang signifikan antara kategori banyaknya melakukan strategi koping ekonomi yang dilakukan oleh keseluruhan keluarga di Desa Kemujan (yaitu desa yang letaknya dekat dengan ibu kota) dan keluarga di Desa Tegalsari (desa yang letaknya jauh dari ibu kota kecamatan).

Hasil penelitian pada Tabel 2 menunjukkan bahwa berdasarkan rata-rata indeks intensitas melakukan kegiatan strategi koping secara keseluruhan adalah 41,47. Proporsi tertinggi berada pada tingkat sedang/sering (indeks 33,4-66,6) yaitu sebesar 87 persen keluarga, sedangkan sisanya 13 persen keluarga berada pada intensitas rendah/jarang (indeks 0,0-33,3), dan tidak ada keluarga yang intensitas melakukan kegiatan strategi koping pada tingkat tinggi/sangat sering (indeks 66,7-100,0). Rata-rata indeks yang dimiliki keluarga di Desa Kemujan lebih tinggi dibandingkan dengan keluarga di Desa Tegalsari. Hasil uji beda menunjukkan tidak terdapat perbedaan yang signifikan antara rata-rata indeks intensitas melakukan strategi koping ekonomi secara keseluruhan di Desa Kemujan dan Desa Tegalsari $(p>0,05)$.

Secara keseluruhan strategi koping ekonomi baik dilihat berdasarkan banyaknya dan intensitas strategi koping, Desa Kemujan lebih banyak dan lebih tinggi intensitasnya dibandingkan dengan keluarga di Desa Tegalsari. Hal ini mengindikasikan bahwa lokasi tempat tinggal sangat menentukan strategi koping yang dilakukan keluarga.

\section{Pengaruh Karakteristik Keluarga terhadap Tekanan Ekonomi}

Model persamaan regresi yang disusun untuk menganalisis pengaruh karakteristik keluarga terhadap tekanan ekonomi memiliki koefesien Adjusted $R$ Square sebesar 0,267. Angka ini menunjukkan bahwa 26,7 persen variabel tekanan ekonomi dapat dijelaskan oleh perubahan variabel karakteristik keluarga dan 73,3 persen dipengaruhi oleh variabel lain yang tidak ada dalam model. Hasil analisis regresi (Tabel 3) menunjukkan bahwa faktor yang mempengaruhi tekanan ekonomi keluarga adalah jumlah tanggungan keluarga $(\beta=0,255$; $p=0,022)$, luas rumah-pekarangan $(\beta=-0,217$; $p=0,028)$, status kepemilikan rumah $(\beta=-0,181$; $p=0,080$ ), dan bantuan pemerintah yang pernah diterima $(\beta=0,241 ; p=0,025)$.

Tabel 3 Koefisien regresi analisis pengaruh karakteristik keluarga terhadap tekanan ekonomi

\begin{tabular}{|c|c|c|c|}
\hline Variabel & $B$ & Beta & Sign. \\
\hline Konstanta & 54,498 & & 0,001 \\
\hline $\begin{array}{l}\text { Usia suami } \\
\text { (tahun) }\end{array}$ & $-0,329$ & $-0,174$ & 0,156 \\
\hline $\begin{array}{l}\text { Jumlah } \\
\text { tanggungan } \\
\text { keluarga (orang) }\end{array}$ & 4,138 & 0,255 & $0,022^{\star *}$ \\
\hline $\begin{array}{l}\text { Lama pendidikan } \\
\text { suami (tahun) }\end{array}$ & 0,855 & 0,109 & 0,264 \\
\hline $\begin{array}{l}\text { Luas rumah- } \\
\text { pekarangan } \\
\text { (ubin) }\end{array}$ & $-0,199$ & $-0,217$ & $0,028^{* *}$ \\
\hline $\begin{array}{l}\text { Pendapatan per } \\
\text { kapita } \\
\text { (Rp000/bulan) }\end{array}$ & 0,000 & 0,004 & 0,970 \\
\hline $\begin{array}{l}\text { Pekerjaan } \\
\text { sampingan suami } \\
(1=\text { memiliki, } \\
0=\text { tidak memiliki })\end{array}$ & $-7,723$ & $-0,158$ & 0,124 \\
\hline $\begin{array}{l}\text { Pekerjaan istri } \\
(1=\text { memiliki, } \\
0=\text { tidak memiliki) }\end{array}$ & $-3,714$ & $-0,085$ & 0,393 \\
\hline $\begin{array}{l}\text { Status } \\
\text { kepemilikan } \\
\text { rumah } \\
(1=\text { memiliki, } \\
0=\text { tidak memiliki) }\end{array}$ & $-7,511$ & $-0,181$ & $0,080^{*}$ \\
\hline $\begin{array}{l}\text { Bantuan } \\
\text { pemerintah yang } \\
\text { pernah diterima } \\
\text { (jenis) }\end{array}$ & 4,716 & 0,241 & $0,025^{\star *}$ \\
\hline$F$ & & $4,607^{\star \star \star}$ & \\
\hline Sig & & 0,000 & \\
\hline $\mathrm{R}^{2}$ & & 0,341 & \\
\hline Adjusted $R^{2}$ & & 0,267 & \\
\hline
\end{tabular}


Hasil yang tersaji pada Tabel 3 menunjukkan bahwa tekanan ekonomi keluarga meningkat dengan bertambahnya jumlah tanggungan keluarga dan jenis bantuan pemerintah yang pernah diterima. Sebaliknya, tekanan ekonomi keluarga menurun seiring bertambahnya luas rumah-pekarangan dan juga perubahan status kepemilikan rumah dari tidak memiliki rumah ke memiliki rumah.

\section{Pengaruh Karakteristik Keluarga dan Tekanan Ekonomi terhadap Strategi Koping Ekonomi}

Pengaruh karakteristik keluarga dan tekanan ekonomi terhadap strategi koping ekonomi dianalisis menggunakan analisis regresi linear berganda. Model yang disusun memiliki koefisien determinasi (Adjusted $R$ Square) sebesar 0,188. Artinya, variabel yang ada dalam model dapat menjelaskan 18,8 persen pengaruhnya terhadap banyaknya kegiatan strategi koping yang dilakukan keluarga. Sementara itu, sisanya yang berjumlah 81,2 persen dipengaruhi oleh variabel lain yang tidak ada dalam model (Tabel 4).

Hasil analisis uji regresi memperlihatkan bahwa banyaknya kegiatan strategi koping yang dilakukan keluarga dipengaruhi secara signifikan oleh usia suami $(\beta=0,411 ; p=0,002)$, pekerjaan sampingan suami $(\beta=0,188$; $p=0,086)$, pekerjaan istri $(\beta=0,198 ; p=0,063)$, dan persepsi tekanan ekonomi $(\beta=0,284$; $p=0,013)$. Hasil ini mengindikasikan bahwa peningkatan kegiatan strategi koping keluarga petani pada daerah rawan banjir dipengaruhi oleh meningkatnya usia dan kepemilikan pekerjaan sampingan suami. Hasil tersebut juga mengindikasikan bahwa usia suami yang lebih tua memiliki pengalaman, waktu luang, dan pola pikir yang lebih maju dibandingkan dengan keluarga petani yang memiliki usia suami lebih muda.

Selain itu, mayoritas usia suami keluarga petani berada pada rentang usia 35-55 tahun yang mana pada usia tersebut keluarga memiliki jumlah anak usia sekolah lebih banyak atau tingkat sekolah anak lebih tinggi sehingga akan lebih sering melakukan kegiatan strategi koping untuk dapat menutupi biaya pendidikan yang lebih banyak. Selain itu, kepemilikan pekerjaan pada istri juga turut serta menambah banyaknya kegiatan strategi koping yang dilakukan oleh keluarga. Peningkatan tekanan ekonomi keluarga maka akan berpengaruh terhadap peningkatan kegiatan strategi koping ekonomi yang dilakukan oleh keluarga petani di daerah rawan banjir.
Tabel 4 Koefisien regresi analisis pengaruh karakteristik keluarga dan tekanan ekonomi terhadap banyaknya strategi koping ekonomi yang dilakukan keluarga

\begin{tabular}{|c|c|c|c|}
\hline Variabel & B & Beta & Sig. \\
\hline Konstanta & 20,113 & & 0,002 \\
\hline $\begin{array}{l}\text { Usia suami } \\
\text { (tahun) }\end{array}$ & 0,288 & 0,411 & $0,002^{* * *}$ \\
\hline $\begin{array}{l}\text { Jumlah } \\
\text { tanggungan } \\
\text { keluarga } \\
\text { (orang) }\end{array}$ & 0,398 & 0,066 & 0,581 \\
\hline $\begin{array}{l}\text { Lama } \\
\text { pendidikan } \\
\text { suami (tahun) }\end{array}$ & $-0,486$ & $-0,167$ & 0,109 \\
\hline $\begin{array}{l}\text { Luas rumah- } \\
\text { pekarangan } \\
\text { (ubin) }\end{array}$ & $-0,015$ & $-0,044$ & 0,676 \\
\hline $\begin{array}{l}\text { Pendapatan } \\
\text { per kapita } \\
\text { (Rp000/bulan) }\end{array}$ & $-0,002$ & $-0,073$ & 0,500 \\
\hline $\begin{array}{l}\text { Pekerjaan } \\
\text { sampingan } \\
\text { suami } \\
(1=\text { memiliki, } \\
0=\text { tidak } \\
\text { memiliki) }\end{array}$ & 3,424 & 0,188 & $0,086^{*}$ \\
\hline $\begin{array}{l}\text { Pekerjaan istri } \\
(1=\text { memiliki, } \\
0=\text { tidak } \\
\text { memiliki })\end{array}$ & 3,207 & 0,198 & $0,063^{*}$ \\
\hline $\begin{array}{l}\text { Status } \\
\text { kepemilikan } \\
\text { rumah } \\
(1=\text { memiliki, } \\
0=\text { tidak } \\
\text { memiliki })\end{array}$ & $-2,052$ & $-0,133$ & 0,228 \\
\hline $\begin{array}{l}\text { Persepsi } \\
\text { tekanan } \\
\text { ekonomi } \\
\text { (indeks) }\end{array}$ & 0,106 & 0,284 & $0,013^{\star *}$ \\
\hline $\begin{array}{l}\text { Bantuan } \\
\text { pemerintah } \\
\text { yang pernah } \\
\text { diterima (jenis) }\end{array}$ & 0,339 & 0,047 & 0,684 \\
\hline $\begin{array}{l}\text { Lokasi } \\
\text { (1=dekat dari } \\
\text { kantor } \\
\text { kecamatan, } \\
0=\text { jauh dari } \\
\text { kantor } \\
\text { kecamatan) }\end{array}$ & 1,064 & 0,069 & 0,504 \\
\hline$F$ & & & $3,080^{* \star *}$ \\
\hline $\begin{array}{l}\text { Sig. } \\
\mathrm{R}^{2} \\
\text { Adjusted } \mathrm{R}^{2}\end{array}$ & & & $\begin{array}{l}0,002 \\
0,278 \\
0,188\end{array}$ \\
\hline
\end{tabular}

Keterangan: * Signifikan pada $\mathrm{p}<0,1$; ${ }^{* *}$ Signifikan pada $p<0,05 ;{ }^{* * *}$ Signifikan pada $p<0,01$

Sementara itu, model untuk menganalisis pengaruh karakteristik keluarga dan tekanan ekonomi terhadap intensitas strategi koping memiliki koefisien determinasi sebesar 0,183. Model tersebut tersaji pada Tabel 5. 
Tabel 5 Koefisien regresi analisis pengaruh karakteristik keluarga dan tekanan ekonomi terhadap skor intensitas strategi koping

\begin{tabular}{|c|c|c|c|}
\hline Variabel & B & Beta & Sig. \\
\hline Konstanta & 34,965 & & 0,002 \\
\hline $\begin{array}{l}\text { Usia suami } \\
\text { (tahun) }\end{array}$ & 0,460 & 0,386 & $0,004^{* *}$ * \\
\hline $\begin{array}{l}\text { Jumlah } \\
\text { tanggungan } \\
\text { keluarga (orang) }\end{array}$ & 0,521 & 0,051 & 0,671 \\
\hline $\begin{array}{l}\text { Lama pendidikan } \\
\text { suami (tahun) }\end{array}$ & $-0,798$ & $-0,161$ & 0,122 \\
\hline $\begin{array}{l}\text { Luas rumah- } \\
\text { pekarangan } \\
\text { (ubin) }\end{array}$ & $-0,018$ & $-0,031$ & 0,771 \\
\hline $\begin{array}{l}\text { Pendapatan per } \\
\text { kapita } \\
\text { (Rp000/bulan) }\end{array}$ & $-0,003$ & $-0,059$ & 0,586 \\
\hline $\begin{array}{l}\text { Pekerjaan } \\
\text { sampingan suami } \\
\text { (1=memiliki, } \\
0=\text { tidak memiliki) }\end{array}$ & 5,493 & 0,178 & 0,106 \\
\hline $\begin{array}{l}\text { Pekerjaan istri } \\
\text { (1=memiliki, } \\
0=\text { tidak memiliki) }\end{array}$ & 5,423 & 0,198 & $0,064^{*}$ \\
\hline $\begin{array}{l}\text { Status } \\
\text { kepemilikan } \\
\text { rumah } \\
\text { ( } 1=\text { =memiliki, } \\
0=\text { tidak memiliki) }\end{array}$ & $-3,477$ & $-0,133$ & 0,230 \\
\hline $\begin{array}{l}\text { Persepsi tekanan } \\
\text { ekonomi (skor) }\end{array}$ & 0,185 & 0,293 & $0,010^{* *}$ \\
\hline $\begin{array}{l}\text { Bantuan } \\
\text { pemerintah yang } \\
\text { pernah diterima } \\
\text { (jenis) }\end{array}$ & 0,690 & 0,056 & 0,627 \\
\hline $\begin{array}{l}\text { Lokasi }(1=\text { dekat } \\
\text { dari kantor } \\
\text { kecamatan, } \\
0=\text { jauh dari kantor } \\
\text { kecamatan) }\end{array}$ & 2,559 & 0,098 & 0,345 \\
\hline$F$ & & $3,012^{* \star \star}$ & \\
\hline Sig. & & 0,002 & \\
\hline $\mathrm{R}^{2}$ & & 0,273 & \\
\hline Adjusted R ${ }^{2}$ & & 0,183 & \\
\hline
\end{tabular}

Keterangan: * Signifikan pada $\mathrm{p}<0,1$; ${ }^{* *}$ Signifikan pada $p<0,05 ;{ }^{* * *}$ Signifikan pada $p<0,01$

Koefisien model regresi yang tersaji pada Tabel 5 menunjukkan menunjukkan bahwa peningkatan skor intensitas strategi koping yang dilakukan keluarga dipengaruhi signifikan positif oleh usia suami $(\beta=0,460 ; p<0,01)$, pekerjaan istri $(\beta=0,423 ; p<0,1)$, dan tekanan ekonomi yang dirasakan keluarga $(\beta=0,185$; $p<0,05)$. Hasil tersebut menegaskan bahwa peningkatan tekanan ekonomi yang dirasakan oleh keluarga serta keluarga dengan suami yang lebih tua dan istri tidak bekerja akan menyebabkan peningkatan intensitas keluarga petani di daerah rawan banjir dalam melakukan strategi koping.

\section{PEMBAHASAN}

Penelitian ini bertujuan untuk menganalisis pengaruh karakteristik keluarga dan tekanan ekonomi terhadap strategi koping keluarga petani di daerah rawan banjir Kecamatan Adimulyo, Kabupaten Kebumen, Provinsi Jawa Tengah. Bencana banjir selalu memberikan dampak dan menimbulkan banyak kerugian baik jiwa maupun materi. Tinggi atau rendahnya kerugian akibat banjir tergantung pada kemampuan manusia untuk mencegah dan menghindari banjir. Penanggulangan banjir dilakukan secara bertahap, yaitu pencegahan, penanganan saat banjir, dan pemulihan setelah banjir (Mislan, 2011).

Hasil analisis memperlihatkan bahwa jumlah tanggungan keluarga berpengaruh positif signifikan terhadap tekanan ekonomi. Artinya, keluarga besar akan mengalami persepsi tekanan ekonomi yang lebih tinggi. Penelitian Arthur (2002) menyebutkan bahwa banyaknya anggota dan tanggungan keluarga berimplikasi pada penurunan kualitas hidup seperti kesehatan, nutrisi, pencapaian pendidikan anak, dan status sosial keluarga. Selain itu, berdasarkan hasil ukuran tingkat kesejahteraan keluarga, hal ini sejalan dengan penelitian Muflikhati (2010) bahwa terbukti keluarga kecil akan berpeluang lebih besar untuk sejahtera daripada keluarga besar.

Selanjutnya, hasil penelitian juga memperlihatkan bahwa luas rumah-pekarangan yang dimiliki keluarga berpengaruh signifikan negatif terhadap persepsi tekanan ekonomi. Hal ini disebabkan anggapan bahwa keluarga yang tidak memiliki luas rumah-pekarangan yang cukup, maka tidak ada lagi sumber daya alam yang dapat dimanfaatkan untuk menambah pendapatan keluarga, seperti memelihara hewan ternak dan menanam tanaman kebutuhan pangan. Hasil penelitian yang dilakukan oleh Wickramasinghe (1995) dan Torres (1988) menyebutkan bahwa pekarangan dapat menghasilkan makanan untuk konsumsi keluarga dan sebagai penyangga ekonomi keluarga pada saat terjadinya fluktuasi harga. Status kepemilikan rumah juga berpengaruh signifikan negatif terhadap persepsi tekanan ekonomi. Dalam hal ini keluarga beranggapan bahwa dengan memiliki rumah sendiri merupakan hal yang penting untuk masa depan sehingga tidak ada rasa khawatir sewaktuwaktu akan terlantar dan tidak memiliki tempat tinggal apabila pemilik rumah sebenarnya akan mengambil haknya. 
Bantuan yang pernah diterima keluarga berpengaruh signifikan positif terhadap persepsi tekanan ekonomi. Hal ini diindikasikan bahwa bantuan pemerintah yang pernah diterima keluarga ternyata tidak dapat mengurangi persepsi tekanan ekonomi. Indikasi selanjutnya bahwa keluarga yang menerima bantuan pemerintah lebih banyak adalah keluarga yang memiliki persepsi tekanan ekonomi yang tinggi (bantuan pemerintah sudah tepat sasaran).

Usia suami berpengaruh signifikan positif terhadap banyaknya dan intensitas strategi koping. Usia seseorang berperan dalam menghadapi kehidupan rumah tangga, karena usia berkaitan dengan kegiatan-kegiatan dan siklus hidup dalam kehidupan berumah tangga (Gupta, 2007). Hasil penelitian juga menyebutkan bahwa istri yang memiliki pekerjaan berpengaruh signifikan positif terhadap banyaknya dan intensitas melakukan strategi koping. Istri yang memiliki pekerjaan merupakan salah satu cara atau strategi untuk mengatasi kesulitan yang dihadapi keluarga. Strategi koping yang dilakukan akan dijadikan sebagai strategi koping berkelanjutan atau biasa disebut strategi nafkah.

Petani yang tidak dapat mencukupi kebutuhan hidupnya akan mengerahkan segala sumber daya yang dimiliki dalam upaya bertahan hidup, salah satunya adalah pola nafkah ganda yang dilakukan dengan cara mencari pekerjaan sampingan dengan mengerahkan seluruh anggota keluarga untuk bekerja dan mendapat tambahan penghasilan (Scoones, 1998). Thornton et al. (2007) menyebutkan secara umum keluarga yang lebih miskin biasanya lebih mengimplementasikan dan merencanakan strategi koping. Hal ini sejalan dengan penelitian Voydanof, Majka, dan Donelly (1988) yang menyebutkan bahwa sumber koping keluarga berasal dari karakteristik keluarga yang mempermudah mengatasi masalah dengan pendekatan mengatasi masalah akan kesulitan, seperti adaptasi atau kohesi keluarga.

Persepsi tekanan ekonomi berpengaruh signifikan positif terhadap banyaknya dan intensitas strategi koping yang dilakukan keluarga. Tingginya tekanan ekonomi yang dirasakan keluarga dapat meningkatkan banyaknya dan intensitas strategi koping. Persepsi tekanan ekonomi dalam keluarga penyebab pemicu munculnya berbagai masalah, tidak hanya masalah ekonomi saja melainkan masalah lainnya yang berkaitan dengan kehidupan keluarga. Penelitian Dennis et al. (2003) menyebutkan bahwa tekanan ekonomi yang ada dalam keluarga diduga juga akan menurunkan fungsi emosional dalam pengasuhan dan meningkatkan rasa depresi.

Hasil penelitian ini juga menyebutkan bahwa persepsi tekanan ekonomi mayoritas keluarga memiliki persepsi tekanan ekonomi kategori sedang, hasil ini sejalan dengan penelitian Tati (2004). Hal ini dikarenakan kesulitan untuk pemenuhan kebutuhan pangan jarang dirasakan. Berdasarkan hasil wawancara, hampir seluruh keluarga memiliki kebiasaan untuk menyimpan hasil panennya (padi) yang digunakan sebagai persediaan sampai menunggu musim panen selanjutnya tiba atau bahkan paceklik. Hasil ini sejalan dengan penelitian Kusumo (2009) yang menyatakan bahwa sebagian keluarga petani padi tidak terlalu merasakan kesulitan dalam hal memenuhi kebutuhan pangan, baik pada musim tanam maupun musim paceklik. Menurut Mardiharini (2005) strategi yang paling efektif dipilih keluarga dalam menyikapi dampak krisis adalah dengan mengurangi pengeluaran untuk makanan dan nonmakanan serta meningkatkan produktivitas usaha. Pada batas tertentu, pengeluaran pangan tidak bisa dikurangi lagi, baik jumlah maupun jenisnya. Bahkan jika perlu, keluarga meminjam uang atau berhutang untuk membeli pangan. Mekanisme koping adalah upaya untuk mengatasi gangguan ketahanan pangan yang dilakukan oleh seluruh anggota rumah tangga petani di luar pekerjaan pokok untuk menambah pendapatan dan untuk memperoleh pangan di luar hasil panen sendiri dalam rangka memenuhi kebutuhan pangan rumah tangga (Yunita et al., 2011).

Ketika mengalami penurunan pendapatan keluarga yang diakibatkan kerugian banjir, keluarga petani lebih banyak melakukan strategi koping mengurangi pengeluaran daripada meningkatkan pendapatan. Hasil ini sejalan dengan penelitian yang dilakukan oleh Sunarti, Johan, dan Haryati (2010). Hal ini diindikasikan kurangnya kesempatan lapangan pekerjaan di lokasi penelitian dan rendahnya lama pendidikan keluarga sehingga kurangnya sumber daya dan keterampilan yang memadai untuk dimanfaatkan guna meningkatkan pendapatan. Selain itu, mekanisme dalam menghadapi kejadian (coping mechanism) terbentuk dan lahir dari pengalaman, pengetahuan, pemahaman, dan pemaknaan terhadap setiap kejadian, fenomena, harapan, dan masalah yang terjadi di sekitarnya. Di sisi lain, pendidikan dan pengetahuan seseorang juga sangat penting dan dipercaya merupakan sebuah investasi untuk masa depan untuk 
meningkatkan status sosial ekonomi keluarga (Kwon et al., 2003). Mekanisme tersebut diteruskan melalui proses sosialisasi dari generasi ke generasi dan pelaksanaannya tergantung pada kadar kualitas pemahaman dan implikasinya dalam kehidupan mereka (Maarif, Pramono, \& Kinseng, 2012).

\section{SIMPULAN DAN SARAN}

Secara keseluruhan penelitian ini menemukan adanya perbedaan persepsi tekanan ekonomi pada lokasi tempat tinggal. Tidak terdapat perbedaan yang signifikan antara banyaknya dan intensitas melakukan strategi koping pada kedua lokasi penelitian. Tekanan ekonomi keluarga meningkat dengan bertambahnya jumlah tanggungan keluarga dan jenis bantuan pemerintah yang pernah diterima. Sebaliknya, tekanan ekonomi keluarga menurun seiring bertambahnya luas rumah-pekarangan dan juga perubahan status kepemilikan rumah dari tidak memiliki rumah ke memiliki rumah.

Tekanan ekonomi keluarga berpengaruh pada strategi koping baik dari sisi jumlah maupun intensitasnya. Faktor lain yang menentukan strategi koping keluarga adalah adalah usia suami, pekerjaan sampingan suami, dan pekerjaan istri. Banyaknya dan intensitas strategi koping yang dilakukan keluarga bertambah dengan bertambahnya usia suami dan kepemilikan pekerjaan pada istri. Banyaknya strategi koping yang dilakukan juga bertambah dengan suami memiliki pekerjaan sampingan.

\section{UCAPAN TERIMA KASIH}

Ucapan terima kasih kepada Badan Kependudukan dan Keluarga Berencana Nasional (BKKBN) yang telah memberikan dana penelitian dan beasiswa.

\section{DAFTAR PUSTAKA}

Arthur, J. L. (2002). Family size and quality of life nexus-case of the Sunyani, Municipality, Ghana. Journal Implication of Family Size on The Quality of Life of People in The Sunyani Municipality.

[BNPB] Badan Nasional Penanggulangan Bencana. (2014). Data dan Informasi Bencana. Diambil dari http://www.bnpb.go.id.

Barrera, M. Jr., Prelow, H. M., Dumka, L. E., Gonzales, N. A., Knight, G. P., Michaels, M. L., Roosa, M. W., \& Tein, J. (2002). Paths from family economic conditions to adolescents' distress: supportive parenting, stressors outside the family, and deviant peers. Journal of Community Psychology, 30, 135-152.

Dennis., Jessica, M. P., Ross, D. C., Scott, B., Jan, B. D., \& Sharon, A. (2003). Economic pressure, maternal depression, and child adjustment in latino families: an exploratory study. Journal of Family and Economic Issues, 24(2).

Elder, G. H Jr. (1995). Inner-city parents under economic pressure: perspectives on the strategies of parenting. Journal of Marriage and the Family, 57, 771-784.

Elder, G. H. Jr., Conger, R. D., Foster, E. M., \& Ardelt, M. (1992). Families under economic pressure. Journal of Family issues, 13, 1. Extracted from PCI Full Text. Published by ProQuest Information and Learning Company.

Feil, J. K. (2012). Coping with Economic Stressors: Religious and Non-Religious Strategies for Managing Psychological Distress (Thesis). Minnesota State University, Minnesota, US.

Gudmunson, C.G. (2010). A Life Course Investigation of financial self-reliance and economic pressure in early adulthood (Dissertation). University of Minnesota, Minnesota, US.

Gupta, G. B. W, (2007). Perempuan pada industry garmen kasus di Desa Pandak Gede, Kecamatan Kediri, Kabupaten Tabanan-Bali. Jurnal Widyanata, 2(2).

Gutman, L. M., \& Eccles, J. S. (1999). Financial strain, parenting behaviors and adolescence's achievement: testing model equivalence between African-American and European American single and twoparent families. Child Development.

Kusumo, R. A. B. (2009). Peran gender dalam strategi koping dan pengambilan keputusan serta hubungannya dengan Kesejahteraan keluarga petani padi dan hortikultura di daerah pinggiran perkotaan (Tesis). Institut Pertanian Bogor. Bogor

Kwon, H. K., Reuter, M. A., Lee, S., Koh, S., \& Ok, S. W. (2003). Marital relationships following the Korean economic crisis: Applying the family stress model. Journal of Marriage and Family, 65(2), 316. Proquest Sociology.

Maarif, S., Pramono, R., Kinseng, R. A., \& Sunarti, E. (2012). Kontestasi pengetahuan dan pemaknaan tentang ancaman 
bencana alam (studi kasus ancaman bencana gunung merapi). Jurnal Penanggulangan Bencana, 3(1), 1-13.

Mardiharini, M. (2005). Family-coping strategi in maintaining welfare during the economic crisis in Indonesia: a case study in rural and urban areas in Bogor, West Java, Indonesia. Jurnal Agro Ekonomi, 23(1), 5470.

McLoyd, V. C. (1990). The impact of economic hardship on black families and children. Psychological Distress, Parenting, and Socioemotional Development, 61.

Mislan. (2011). Bencana banjir, pengenalan karakteristik, kebijakan penanggulangannya di Provinsi Kalimantan Timur. Mulawarman Scientifie, 10(1).

Muflikhati, I. (2010). Analisis dan pengembangan model peningkatan kualitas sumber daya manusia dan kesejahteraan keluarga di wilayah pesisir Provinsi Jawa Barat (Disertasi). Institut Pertanian Bogor, Bogor.

Scoones, I. (1998). Sustainable Rural Livelihoods: A framework for analysis. IDS Working Paper, 72. Institute of Development Studies.

Sunarti, E. (2012). Work Stability, Economic Pressure, and Family Welfare. Bogor Agricultural University, Bogor.

Sunarti, E., Johan, I. R., \& Haryati, C. (2010). Hubungan fungsi agil dengan kesejahteraan keluarga nelayan yang rawan terkena bencana alam. Jurnal IImu Keleluarga \& Konsumen, 3(1), 11-17. ISSN: 1907-6037.
Tati. (2004). Pengaruh tekanan ekonomi keluarga, dukungan sosial dan kualitas perkawinan terhadap pengasuhan anak (Tesis). Institut Pertanian Bogor, Bogor.

Thornton, P. K., Boone, R. B., Galvin, K. A., Burnsilver, S. B., Waithaka, M. M., Kuyiah, J., Karanja, S., Estrada, E. G., \& Herrero, M. (2007). Coping strategies in livestockdependent household in. East and South Africa: A synthesis of four case studies, 35, 461-476. doi 10.1007/ s10745-007-9118-5. Springer Science + Business Media, LLC.

Torres, E. B. (1988). Sosioeconomic aspect of backyard gardening in the Philippines. Council for Agriculture, Foresty and Natural Resources Research and Development. Report, 69.

Voydanof, P., Majka, L. C., \& Donelly. (1988). Families and Economic Distress: coping strategies and social policy. Newbury Park, US: Sage Publication Inc. First Printing.

Wickramasinghe, A. (1995). Home Gardens: Habitations Rescuing Biodiversity. MPTS News, 4,1-4.

Whitbeck, L. B., Simons R. L., Conger R. D., Lorenz F. O., Huck S., \& Elder, G. H. Jr. (1991). Family economic hardship, parental support, and adolescent selfesteem. Social Psychology Quarterly, 54, 353-363.

Yunita., Ginting, B., Asngari, P. S., Susanto, D., \& Amanah, S. (2011). Ketahanan pangan dan mekanisme koping rumah tangga petani padi sawah lebak berdasarkan status kepemilikan lahan. Jurnal IImu Keluarga \& Konsumen., 4(1), 21-29. 